\section{Havfrue af Anne Marie Carl-Nielsen}

\author{
af professor, billedhugger Morten Strade
}

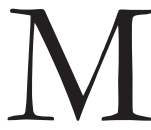
ed meget lærde Carl Nielsen eksperter på den ene side, og vin og kage på den anden er det nok passende at jeg fatter mig $i$ korthed.

Jeg skal holde mig fra at udlægge de personalhistoriske fakta omkring Havfrue, i dette selskab af kyndige mennesker. Men jeg kan ganske kort se på hendes værk med en kollegas blik.

Anne Marie Carl-Nielsen har selv for en billedhugger som jeg selv, ikke indtil nu haft en særlig fremtrædende placering. Jeg var godt klar over hendes eksistens, og kender også enkelte af hendes værker. Men det er nok ikke forkert at sige, at hun som hos mig, også i de flestes øjne står i skyggen af hendes mand.

I hendes samtid var hun væ- hendes atelier).

Jeg blev faktisk forst opmærksom på hendes arbejde på udstillingen Livslyst på Kunstmuseet Fuglsang, hvor hun var repræsenteret med en håndfuld ret små bronzer i skitseform af sportsudøvere, som havde en direktehed som på visse plan kan sammenlignes med Adam Fischers sangomspundne lille futuristiske fodboldspiller fra 1913.

I disse tider, hvor "den lille havfrue"-ophidselsen hærger i medierne fordi man vil flytte Edvard Eriksens mådelige skulptur til Kina, er det opløftende at se en skulptur, som på mere ramsaltet vis tager livtag med det menneskedyr, som havfruen er. Anne Marie Carl-Nielsens havfrue nærer sig ikke ved litteratur, men henvender sig med kunstens "lange og tørre liv"direkte til hver enkelts "korte, komplicerede og fugtige liv" for nu at citere Per Aage Brandt.

Personlig har jeg aldrig kunnet se kvaliteterne ved Den Lille Havfrue, udover de iøjefaldende sentimentale, og den PR-mæssigt geniale kobling til H.C Andersens eventyr af samme navn, så ikke mindst derfor er det glædeligt, at skulpturen her har fået en prominent plads ved vandet, som kan tage konkur- sentlig mere påagtet.

Derom vidner de store

offentlige skulpturer hun udførte og æresboligen mindre end 100 meter herfra. Den æresbolig HUN rent faktisk havde i Kunstakademiets lokaler på Frederiksholms Kanal. Jeg har selv under min uddannelse stået på
5. maj 2009 fik København en ny havfrue. Det Kongelige Bibliotek satte en bronzekopi af Anne Marie Carl-Nielsens skulptur Havfrue op på havnefronten ved Den Sorte Diamant. Ved afsløringen holdt billedhugger, professor Morten Stræde, bestyrelsesmedlem af Carl Nielsen og Anne Marie Carl-Nielsens Legat, denne tale. Legatet har bekostet udførelse og opsætning af skulpturen som en gave til Det Kongelige Bibliotek. rencen om havneløbet op.

Selve skulpturen skriver sig ind i den symboltunge del af billedkunsten fra forrige århundrede, som også tæller billedhuggere som J.F. Willumsen, Rudolf Tegner, Carl Milles og den er lidt en særling i Anne Marie 
Carl-Nielsens værk, som ellers for mig $i$ alt fald er kendetegnet ved en langt større vægtning af det konkrete. Hun er ikke modernist, og holder derfor fast i motivet, fortællingen, fagets store historie osv. og måske derfor "skrider hun ud" i dette værk i symbolistisk retning. Der var mange havfruer $\mathrm{i}$

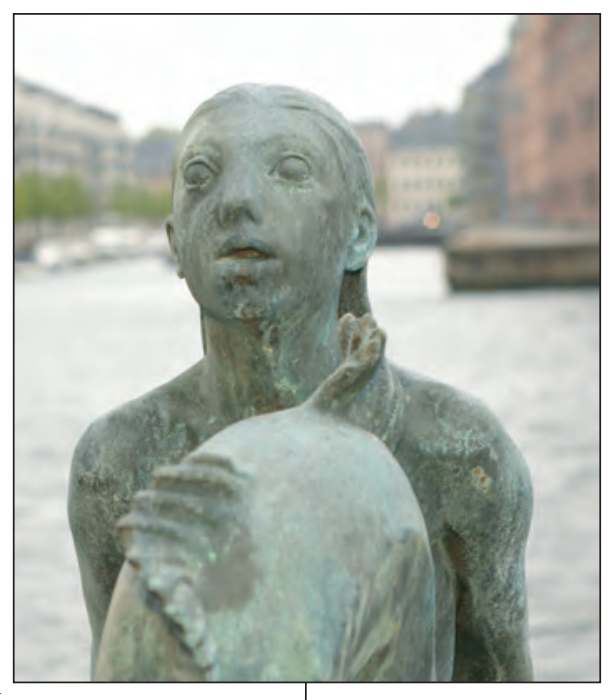
konkret og slagkraftig retning. Hvis jeg igen vender mig til Havfrue, hænger motivet godt sammen med andre af de kvindefigurer, hun arbejdede med. Dronning Dagmar, Margrethe den 1. Det selvbiografiske ligger snublende nær, for det må have krævet adskilligt af hende at hævde sig som kunstner, tiden, stort set alle de ovennævinte billedhuggere har lavet én omkring samtidig. Symbolismen var for mig at se svaret på de nye tider for de billedkunstnere som godt nok ville noget nyt, men som ikke tog springet til modernismen, og det er nok i den produktive kunsthistoriske blindgyde, man skal se denne figur.

Anne Marie Carl-Nielsens fabelagtige monument til Carl Nielsen, som står på Oslo plads, og på forbløffende vis formår at holde et meget kompliceret og trafikbelastet rum samlet, tror jeg viser hvad jeg mener med forholdet mellem symbol og det konkrete. Mig bekendt var hesten, Carl sidder på, oprindelig forsynet med vinger, en Pegasus. Men økonomien satte en stopper for det, og den nuværende figur blev resultatet: en helt almindelig hest spændt sammen på en alt for lille sokkel med en dreng på ryggen. Selvom det ikke var hensigten, flyttede omstændighederne - og selvfølgelig billedhuggeren - værkets udtryk i en meget mere direkte, ovenikøbet i en (stadig i vore dage) mandsdomineret del af billedkunsten, nemlig skulpturen, og samtidig undgå at blive kørt over af sin mand.

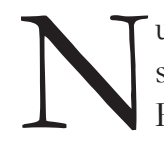
u står den her og gør det, som skulpturer er bedst af alle til: Fastholder en bevidsthed, en holdning, en ideologi og en historie, og sætter en kommenterende kile ind $i$ vores tid med den samtidighed, som billedkunst er kendetegnet ved - hvis den vel at mærke får lov at stå i det offentlige rum i længere tid end "mands minde".

Den kan fortælle om en datid, hvor den blev frembragt, en nutid hvor vi opstiller skulpturen (og hvilke overlejringer der er mellem de to perioder). Den kan tale om den kunsthistorie, skulpturen skriver sig ind i, og fortælle om kunstneres betingelser, ikke mindst de kvindelige kunstners betingelser.

Og den gør det uden diminutiver og uden sentimentalitet... 